\title{
Occurrence of Erysiphe necator Chasmothecia and Their Natural Parasitism by Ampelomyces quisqualis
}

\author{
Dario Angeli, Elisabetta Pellegrini, and Ilaria Pertot
}

Plant Protection Department, Fondazione Edmund Mach (FEM), 38010 S. Michele all'Adige (TN), Italy. Accepted for publication 31 December 2008.

\begin{abstract}
Angeli, D., Pellegrini, E., and Pertot, I. 2009. Occurrence of Erysiphe necator chasmothecia and their natural parasitism by Ampelomyces quisqualis. Phytopathology 99:704-710.

In northern Italy, Erysiphe necator overwinters almost exclusively as chasmothecia. From 2004 to 2008, we investigated the occurrence of natural parasitism of grapevine powdery mildew chasmothecia by Ampelomyces quisqualis in the Trentino-Alto Adige region, in northern Italy. The survey was conducted in 18 vineyards in autumn 2004 and 2005 and in 45 vineyards in autumn 2006 and 2007. The incidence of powdery mildew signs (white powdery mycelia and conidia), the number

parasitism by A. quisqualis were assessed. The production of E. necator chasmothecia on leaves is related to the incidence and severity of the disease on leaves at the end of the season and is not correlated with the elevation of the vineyard, which is inversely related to the temperature. A limited amount of natural parasitism of E. necator by Ampelomyces spp. $(0.17$ to $3.51 \%)$ was observed in all of the years of the survey. Pycnidia and conidia of Ampelomyces spp. parasitizing E. necator chasmothecia were found in conventional, organically grown, and untreated vineyards. Some of the isolated Ampelomyces strains have conidia that are shaped differently than those of the commercial A. quisqualis strain (AQ10) and are phylogenetically different from AQ10.
\end{abstract} of chasmothecia and their development pattern, and the incidence of
Grapevine powdery mildew, caused by the obligate biotrophic fungus Erysiphe necator Schwein., is one of the most important grapevine diseases in Italy because of the presence of pathogen inoculum and favorable environmental conditions for its development. Uncontrolled epidemics of E. necator may result in yield losses, as well as a reduction in the quality of the produced wine $(9,21)$. During the winter, the fungus survives either as mycelium in the dormant buds of grapevine or as chasmothecia, which are the fruiting bodies arising from the sexual stage $(3,24)$. Mycelium preserved inside the bud is thought to give rise to so-called flag shoots in spring. The infected flag shoots are stunted, deformed, and covered with white powdery mycelium and conidia (25). In contrast, chasmothecia represent the main source of primary inoculum in regions with cold winters, such as are found in northern Italy. In the spring, ascosporic infections originating from chasmothecia commonly appear randomly in the vineyard as scattered whitish and powdery spots on leaves (1 to $3 \mathrm{~mm}$ in diameter) that mainly appear on leaves close to the trunk $(10,23,27,37)$. Grapevine is one of the most important crops in Trentino-Alto Adige (northern Italy), with a cultivated area of $\approx 10,000$ ha. Chasmothecia are thought to be the main overwintering form of $E$. necator in this region (2).

Ampelomyces quisqualis Ces. is a naturally occurring mycoparasite of several powdery mildew species (Erysiphales), including $E$. necator $(5,14,30)$. A . quisqualis has been considered to be a single species for a long time but its taxonomy has become controversial and probably merits extensive revision (16). The morphology of the conidia and pycnidia of different A. quisqualis isolates and the growing patterns of colonies of these isolates on laboratory media are highly variable (17). The pycnidia of Ampelomyces spp. also vary in shape depending upon the fungal structure in which they were formed. They are pear-shaped,

Corresponding author: D. Angeli; E-mail address: dario.angeli@iasma.it

doi:10.1094/PHYTO-99-6-0704

(C) 2009 The American Phytopathological Society spindle-shaped, or nearly spherical when they are formed inside E. necator conidiophores, hyphae, or chasmothecia, respectively. Pycnidia contain cylindrical to spindle-shaped conidia, which are occasionally curved and two-spotted (5). Recent molecular studies have hypothesized the existence of more than one species in the genus Ampelomyces. Analyses of the internal transcribed spacer (ITS) region of the nuclear ribosomal RNA gene (nrDNA) of several putative A. quisqualis strains have uncovered a high level of genetic diversity $(13,16,29,32)$, which suggests that the binomial A. quisqualis should be regarded as a species complex (16).

A. quisqualis has been found on more than 64 species of powdery mildew on 256 species of plants $(13,15,17)$. This wide host range, combined with tolerance to a number of fungicides used against powdery mildews, makes $A$. quisqualis the ideal candidate for use as a biological control agent $(6,31,34)$. An A. quisqualis strain isolated in Israel has been formulated, registered, and commercialized in several countries under the trade name "AQ10" (33).

A. quisqualis can grow saprophytically for short periods of time but has little chance of surviving for longer periods in natural environments without parasitizing a powdery mildew host. It requires water to germinate and to infect powdery mildew colonies. Infections can occur in less than $24 \mathrm{~h}$ at $25^{\circ} \mathrm{C}(17,30)$. A. quisqualis invades and grows within powdery mildew hosts $(12,30)$. Parasitized powdery mildew colonies are dull, flattened, and offwhite to gray in color. Pycnidia are formed within hyphae, conidiophores, conidia, and the immature chasmothecia of powdery mildews. Once the mycoparasite has begun to produce pycnidia, the hyphae and conidiophores swell to several times their normal diameter and the amber color of the pycnidial walls of A. quisqualis may be visible through the cell walls of the host (5). Several studies have shown that A. quisqualis cannot parasitize mature E. necator chasmothecia $(5,17)$. Parasitized chasmothecia are typically dull, fawn-colored, flaccid, and 64 to $130 \mu \mathrm{m}$ in diameter (5). A. quisqualis parasitism reduces powdery mildew sporulation as well as the production of chasmothecia and may eventually kill the entire mildew colony $(5,6,12,17,30)$. 
Whereas a few studies have reported the presence of A. quisqualis on several powdery mildews on several plants $(14,17)$, no study has reported on the extent of the natural occurrence of $A$. quisqualis on grapevine powdery mildew. The aims of this study were to (i) assess and quantify the presence of Ampelomyces spp. on grapevine powdery mildew in a wide viticulture area in northern Italy (Trentino-Alto Adige region) and (ii) characterize the isolates present in the area. We also evaluated the occurrence of chasmothecia the in Trentino-Alto Adige region and monitored their development in the vineyard.

\section{MATERIALS AND METHODS}

Study sites, assessment, and sampling. The study was carried out from 2004 to 2007 in the Trentino-Alto Adige region of northern Italy. Sampling was carried out between 15 and 31 October in 18 vineyards from 2004 to 2007. Additionally, 27 vineyards were sampled in 2006 and 2007, respectively. The vineyards were randomly selected. The sampled vineyards included conventionally and organically managed vines; abandoned (untreated) vineyards were also surveyed. The chemical fungicides used in the conventionally managed vineyards included mancozeb, folpet, dimethomorph, zoxamide, iprovalicarb, quinoxyfen, spiroxamine, copper, sulfur, acylalanines, strobilurins, and triazoles. In the organic vineyards, only sulfur and copper were used. A. quisqualis (AQ10; Ecogen, Langhorne, PA, USA) was not used in any of the monitored vineyards during the survey period. The size of each sampled vineyard was 800 to $1,200 \mathrm{~m}^{2}$. In each vineyard and year, four replicates of 25 leaves each were randomly collected at the fifth leaf from the shoot. For each replicate, the percentage of infected area on the upper surface of the leaf (whitish, powdery spots) and the number of infected leaves were visually assessed. Disease severity (percentage of infected leaf area) and incidence (percentage of infected leaves) were calculated. A disk ( $2 \mathrm{~cm}$ in diameter) was cut from the central part of each sampled leaf. The E. necator chasmothecia on the upper side of each leaf disk were counted under a dissecting microscope (Nikon SMZ 800, Tokyo). To identify the optimal times for assessing parasitism by and development of Ampelomyces spp., the ripening of chasmothecia was surveyed weekly between August and November in an untreated experimental vineyard (cv. Schiava) in S. Michele all'Adige on a sample of 100 randomly collected leaves. The number of chasmothecia was assessed as described above. Chasmothecia were classified into three categories according to their color, which reflects their development stage: yellow (young), brown (semi-mature), and black (mature). On each leaf (100 leaves per vineyard, collected when black chasmothecia were $50 \pm 10 \%$ ), Ampelomyces spp. mycoparasitism of E. necator was assessed under a light microscope (Hund Wetzlar H 600LL, Wetzlar, Germany), in terms of the presence of parasitized dull, flaccid, and fawn-colored chasmothecia, brownish intracellular pycnidia in E. necator hyphae, or cylindrical, spindle-shaped, and two-spotted conidia. In detail, E. necator mycelium and chasmothecia were transferred into Eppendorf tubes by brushing the upper surface of sampled leaves (four tubes for each replicate of 25 leaves) and stored at $4^{\circ} \mathrm{C}$. One hundred chasmothecia from each tube were mounted in lactophenol and observed under a light microscope to asses the percentage of parasitized cleistothecia as well as the presence of Ampelomyces spp. pycnidia and conidia. Ampelomyces spp. infect and produce pycnidia only inside young and semi-mature chasmothecia, as reported in several studies of parasitism of E. necator $(5,17)$, when black chasmothecia were $50 \pm 10 \%$ of the total; therefore, we selected yellow and brown chasmothecia and excluded mature, dark-brown chasmothecia. Chasmothecia were gently crushed by pressing the cover slip over the glass slide on which the sample was spread, to allow the release of Ampelomyces spp. conidia and pycnidia. The possible presence of Ampelomyces spp. pycnidia in the sample was recorded. The incidence of Ampelomyces spp. in each vineyard was calculated as the percentage of E. necator chasmothecia parasitized by Ampelomyces spp. During 2005 to 2008, between April and May of each year, the vineyards were monitored weekly to check for the presence of flag shoots.

Isolation, identification, morphological, and molecular characterization of isolates of Ampelomyces spp. Ampelomyces spp. samples on parasitized chasmothecia and mycelia were initially identified by comparing the morphological characteristics of the observed conidia and pycnidia with those described in the literature $(5,14,17)$. Some of the Ampelomyces spp. samples were isolated by transferring the conidia onto potato dextrose agar (PDA) (Oxoid, Hampshire, UK) amended with 2\% chloramphenicol (Sigma-Aldrich, St. Louis). Morphological identification and measurements of pycnidia and conidia (length, width, and shape) were carried out on 20 replicates (pycnidia) for each isolate. Five isolates (ITA 1, ITA 2, ITA 3, ITA 4, and ITA 5) were selected for the genetic analysis, each representing the different morphological shapes (fusiform or ellipsoid) found in homogeneous areas of the Trentino region (Trento North, Trento South, and Rovereto). The mycelium of each of five 20-day-old Ampelomyces spp. isolates grown on PDA was collected from petri dishes and freeze-dried. DNA was extracted from $2 \mu \mathrm{g}$ of homogenized lyophilized mycelia, using the Nucleo Spin Plant Kit (MachereyNagel, Düren, Germany) according to the manufacturer's instructions. The ITS region of the nrDNA was amplified using the specific fungal primers ITS1 and ITS4 (36). PCR was performed in the Gene Amp PCR System 9700 (Perkin-Elmer, Waltham, MA, USA) and the following cycling parameters were used: initial denaturing step at $95^{\circ} \mathrm{C}$ for $3 \mathrm{~min} ; 35$ cycles of denaturing step at $95^{\circ} \mathrm{C}$ for $30 \mathrm{~s}$, primer annealing at $60^{\circ} \mathrm{C}$ for $30 \mathrm{~s}$, and extension step at $72^{\circ} \mathrm{C}$ for $30 \mathrm{~s}$; and a final extension at $72^{\circ} \mathrm{C}$ for 7 min. PCR products were detected by electrophoresis on $1 \%$ agarose gel in Tris-borate-EDTA (TBE) buffer supplemented with ethidium bromide $(0.5 \mu \mathrm{l} / \mathrm{ml})$. PCR products were purified using the ExoSAP-IT enzymes (USB Corporation, Staufen, Germany) and sequenced using a Big Dye Terminator Cycle Sequencing Kit (v1.1; Applied Biosystems, Foster City, CA). Both DNA strands were sequenced with the primers used for PCR amplification; electrophoresis was carried out using an ABI 3130xl Genetic Analyzer (Perkin-Elmer). The consensus sequence was assembled using Pregap4 and Gap4 (28). Searches were performed in the National Center for Biotechnology Information or GenBank database to find the closest relatives of the sequenced isolates and the similitude percentages through the BLAST method (1). The ClustalW2 program, available for free on the internet (18), was used to construct multiple sequence alignments using the DNA identity matrix and to visualize the evolutionary relationship between the input sequences. The alignments were checked and edited using BioEdit 7.0.5.2. (11) to generate an alignment of the same length for inferring phylogenies. Maximum-likelihood and neighbor-joining analyses based on ITS region sequences were conducted using the programs BioEdit 7.0.5.2. and Mega4, respectively (35), with the Jukes-Cantor substitution model and with rate uniformity among sites. All positions containing gaps and missing data were eliminated. The branches of the inferred tree were tested by bootstrap analysis (7) with 1,000 replicates. The trees were visualized using TreeView 1.6.6 (22).

Meteorological data and statistical analysis. Meteorological data (rain, hourly temperature, and relative humidity) were collected by the local agrometeorological service (available online). Sum of hours with optimal temperatures $\left(20\right.$ to $\left.27^{\circ} \mathrm{C}\right)$ for powdery mildew infection and disease development and total rain (24) were calculated from 1 May to 31 October. Statistical analyses were performed using Statistica software (v. 6.0; Statsoft, Tulsa, $\mathrm{OK})$. Disease incidence and severity data were arcsin transformed to normalize the data. One-way analysis of variance (ANOVA) was used to compare differences in the incidence and severity in 
the different years. Means were separated using Tukey's test ( $\alpha=$ $0.05)$. The $\chi^{2}$ test followed by Ryan's multiple comparison test $(P \leq 0.05)(26)$ was used to compare differences in the presence of Ampelomyces spp. in the different years.

\section{RESULTS}

Natural occurrence of $\boldsymbol{E}$. necator. The assessment of powdery mildew infections in the sampled vineyards at the end of the growing seasons detected increases in disease severity and incidence between 2004 and 2007 (Fig. 1). The monitoring showed both high incidences and high severity of E. necator infections in 2006 and 2007 (34 and $45 \%$ of average severity and 45 and $67 \%$ of average incidence in all vineyards, respectively), probably because of the favorable climatic conditions for powdery mildew (24) present after veraison through the end of the growing season (Fig. 2). In 2006 and 2007, it was cooler and rainier during the last part of the season compared with the earlier seasons (data not shown). Similar to the findings concerning disease severity and disease incidence on leaves, the populations of E. necator chasmothecia were lower in 2004 and 2005 than they were in 2006 and 2007 (Fig. 3). There was a very high correlation between the severity of powdery mildew infections on leaves in the vineyard (average of the four replicates) and the number of E. necator chasmothecia per unit of leaf area (average of the four replicates)
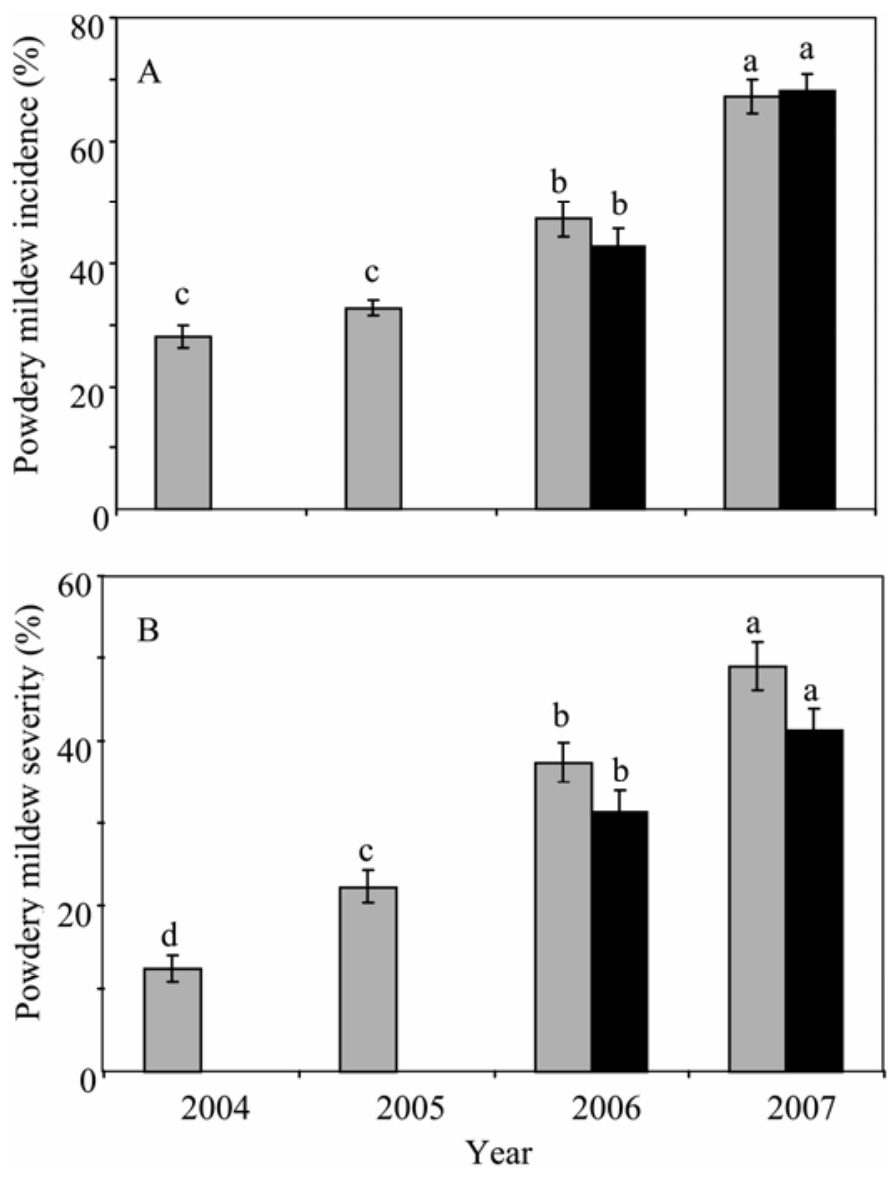

Fig. 1. A, Average powdery mildew incidence (percentage of leaves that were infected) and $\mathbf{B}$, severity (percentage of leaf area that was infected) in vineyards in the Trentino-Alto Adige region that were sampled at the end of each growing season (15 to 31 October). Four replicates (25 leaves per replicate) were assessed in each vineyard. Gray bars indicate the average of the 18 vineyards monitored over the 4 years; black bars indicate the average values in the 27 vineyards that were only surveyed in 2006 and 2007. Error bars represent one standard error of the mean. Columns with the same letter (a to d) are not significantly different from one another $(P \leq 0.05)$ according to Tukey's test.
(Fig. 4). A similar high correlation was observed between powdery mildew incidence and the number of chasmothecia per unit of leaf surface area. In 2004, 2005, 2006, and 2007, $R^{2}$ values were $0.938(y=4.3898 x-63.046), 0.952(y=4.6758 x-65.763)$, $0.984(y=5.4574 x-88.023)$, and $0.972(y=6.2413 x-156.83)$, respectively. There was no correlation between the number of chasmothecia per unit of leaf area and the elevation of the different vineyards, which is inversely related to temperature. No flag shoots were seen in the vineyards in the years of the survey and infections began (seemingly) randomly in the monitored vineyards.

Development of powdery mildew chasmothecia. Almost identical results were obtained during each of the 4 years of the survey. Therefore, only data collected in 2005 are presented here. The first signs of the initial development of chasmothecia were observed on E. necator-infected leaves in the experimental vineyard of S. Michele all'Adige in the beginning of August. The number of translucent white masses, which represent the primary stage of chasmothecia formation, quickly increased during August while the amount of dark, mature chasmothecia began to increase rapidly after the middle of October (Fig. 5).

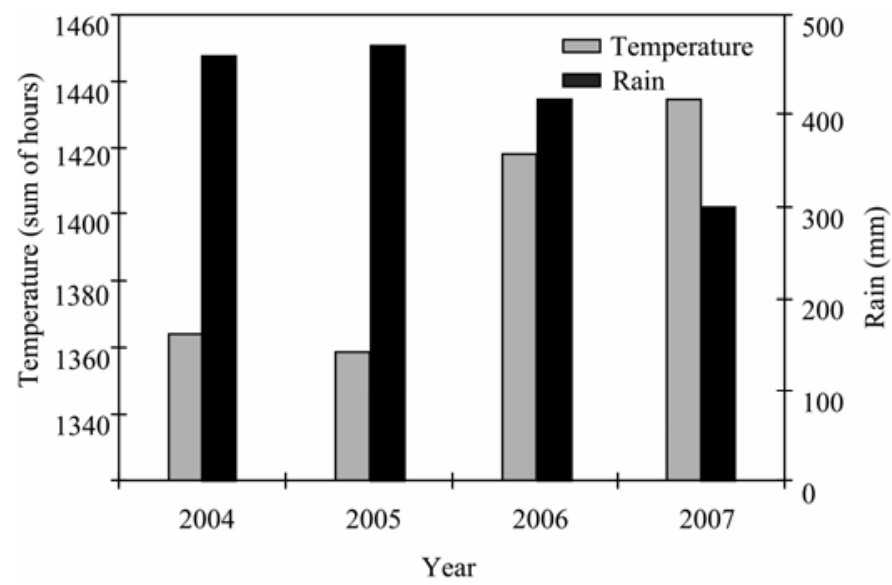

Fig. 2. Periods with suitable temperature for powdery mildew (sum of hours with temperature of 20 to $27^{\circ} \mathrm{C}$ ) and total rain from 1 May to 31 October of each year in S. Michele all'Adige (Trentino-Alto Adige region).

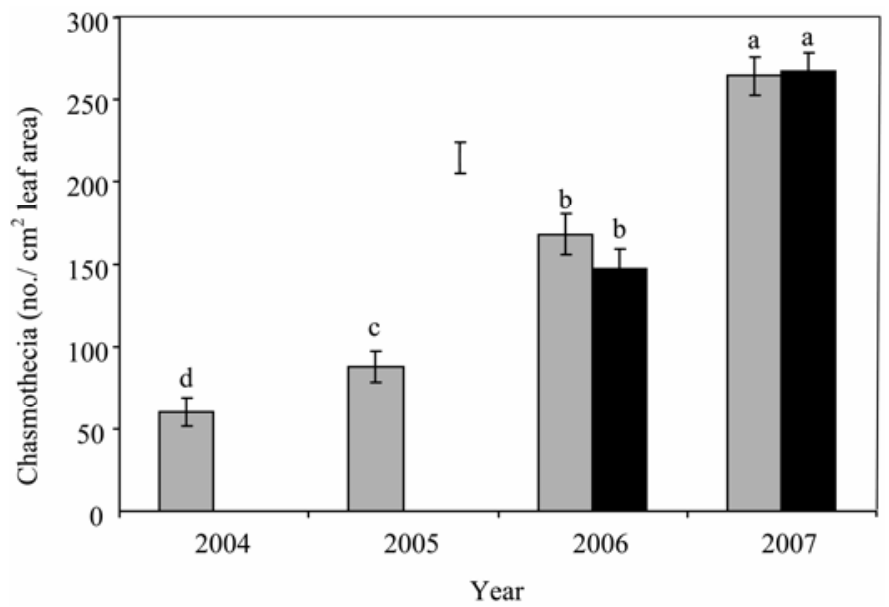

Fig. 3. Number of chasmothecia of Erysiphe necator per unit of leaf area $\left(\mathrm{cm}^{2}\right)$ in the sampled vineyards in the Trentino-Alto Adige region at the end of each growing season (15 to 31 October). Four replicates (25 leaves per replicate) were collected and chasmothecia were counted on leaf disk samples cut from the middle of each leaf. Gray bars indicate the average value for the 18 vineyards monitored for the 4 years; black bars indicate the average values for the 27 vineyards that were only surveyed in 2006 and 2007. Error bars represent the standard errors of the means. Columns with the same letter (a to d) are not significantly different $(P \leq 0.05)$ according to Tukey's test. 
Occurrence of Ampelomyces spp. in E. necator. E. necator chasmothecia were naturally parasitized by Ampelomyces spp. and fruiting bodies of the mycoparasite (pycnidia and conidia) were found throughout the Trentino-Alto Adige region on leaves of different vine cultivars. Some of these cultivars are highly susceptible to powdery mildew (e.g., Schiava, Muller Thurgau, Lagrein, Teroldego, Marzemino, and Chardonnay), some are moderately susceptible (e.g., Nosiola, Traminer, Pinot Gris, and Pinot Noir) and some are not susceptible at all (e.g., Riesling, Merlot, Cabernet Sauvignon, and Moscato Giallo). The results of this 4-year monitoring program underline the generally low natural presence of Ampelomyces spp. in the vineyards of the Trentino-Alto Adige region (Table 1).

In the first 2 years, no differences in the percentage of parasitism in the vineyard were seen but the total number of chasmothecia parasitized by Ampelomyces spp. significantly increased over the period of the study $\left(\chi^{2}=102.98 ; \mathrm{df}=3 ; P \leq 0.001\right)$. The average rate of parasitism among chasmothecia in all of the monitored vineyards ranged from $0.17 \%$ (2004) to $3.51 \%$ (2007). Once Ampelomyces spp. were first found in a vineyard, it was also found in that vineyard in following years. Ampelomyces spp. were found on leaves, mainly as conidia in parasitized E. necator chasmothecia, and, in four vineyards, as pycnidia in the powdery mildew mycelia. Because of the limited number of E. necator samples parasitized by Ampelomyces spp. and the limited numbers of available untreated or abandoned and organic vineyards in the area, no relationship between treated (conventional and biological treatments) or untreated or abandoned vineyards and A. quisqualis parasitism of powdery mildew could be identified. A weak relationship was observed between the number of chasmothecia per unit of leaf surface area and the percentage of chasmothecia parasitized by Ampelomyces spp.

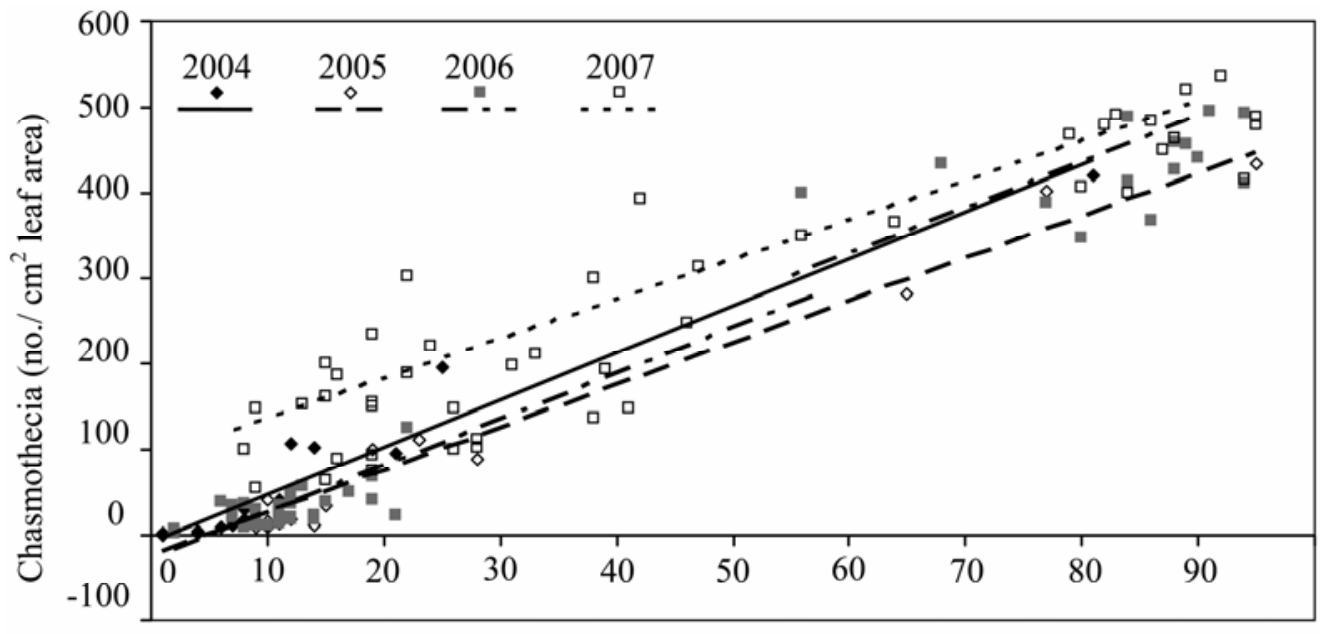

Powdery mildew severity (\%)

Fig. 4. Correlation between powdery mildew severity and the number of chasmothecia per unit of leaf area in the monitored vineyards in the Trentino-Alto Adige region at the end of the growing season (2004 to 2007). Four replicates (25 leaves per replicate) were surveyed for disease incidence and one disk was excised from each leaf for the chasmothecia counting.

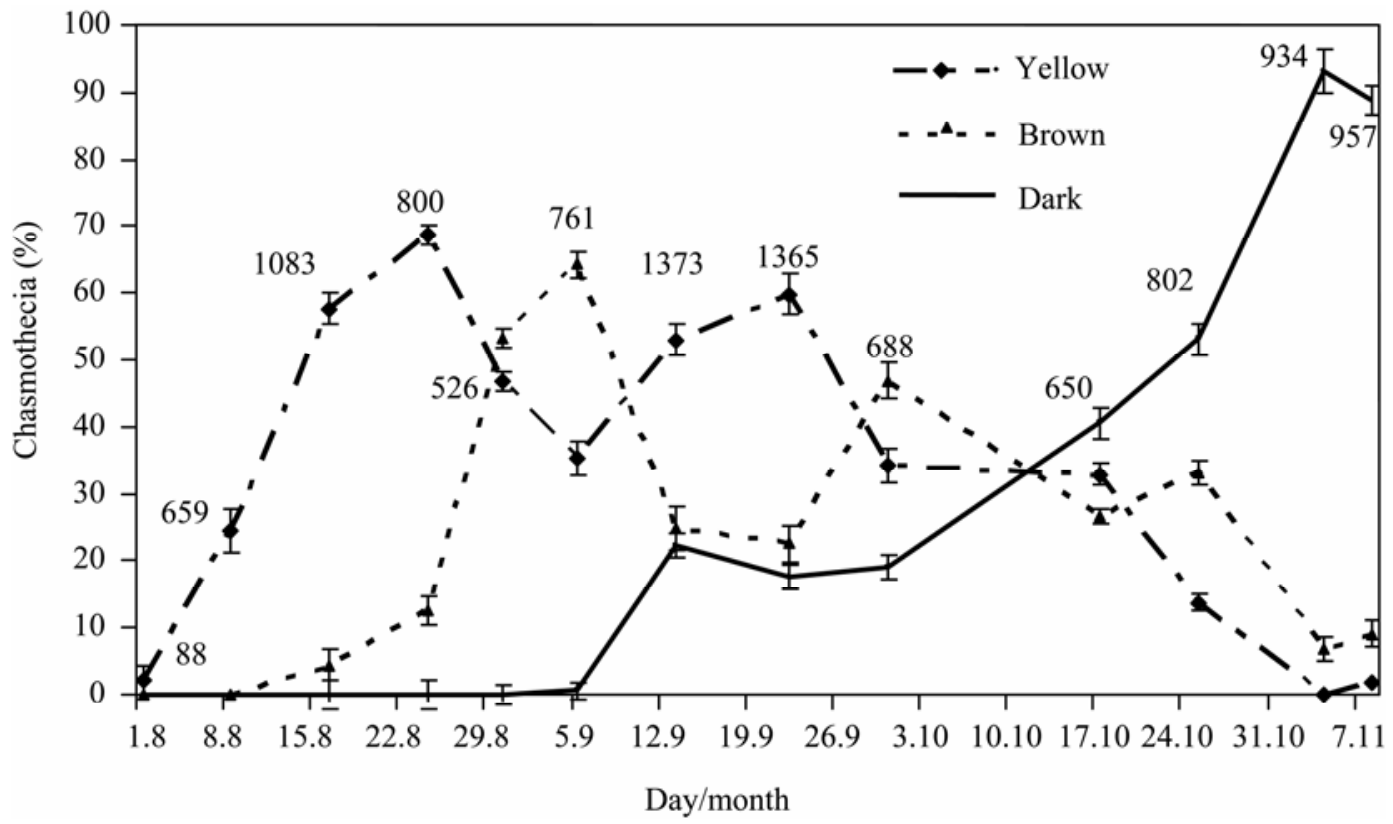

Fig. 5. Development of chasmothecia of Erysiphe necator on leaves in an untreated vineyard in S. Michele all'Adige in 2005. Each week, the number of chasmothecia on a sample of 100 infected leaves (one leaf disk, $1 \mathrm{~cm}$ in diameter, cut from the central part of each leaf) was counted. The percentages of young (yellow), semi-mature (brown), and mature (dark brown) chasmothecia per square centimeter of upper leaf surface were determined. Error bars represent one standard error of the mean. Numbers represent the total number of chasmothecia counted on each date. 
during the period 2004 to $2007\left(R^{2}=0.366, y=7 \mathrm{E}-0.5 x^{2}-\right.$ $0.0165 x+0.5218)$.

Identification and morphological characterization of Ampelomyces spp. Pycnidia of the Ampelomyces spp. isolates varied in shape (ovoid, ellipsoid, or globose). They were found only in powdery mildew mycelia. No pycnidia were observed in immature or semi-mature chasmothecia. Moreover, the ranges of pycnidia sizes were quite variable.

Conidia of Ampelomyces spp. were found in chasmothecia and in mycelia. Conidia size was variable within isolates. The conidia were 11.5 to $14.5 \mu \mathrm{m}$ in length (major axis) and 2.5 to $3.5 \mu \mathrm{m}$ in width (minor axis). Differences in the shape (fusiform or ellipsoidal) of the conidia were observed among isolates collected in different vineyards (Table 2). Molecular analysis, based on ITS sequencing, showed that all of the collected isolates belong to the Ampelomyces genus. The most similar NCBI library strains are listed in Table 3, together with their accession numbers and similarity percentage figures. The ITS sequences of the five selected Ampelomyces strains were analyzed together with the sequence obtained from AQ10 and with other Ampelomyces sequences from GenBank, from different collections and from different host species, in order to evaluate their phylogenetic diversity. An alignment 511 nucleotides long was used to infer phylogenies. Both the maximum-likelihood (not shown) and the neighbor-joining trees (Fig. 6) showed the same clustering of the strains. The five wild strains grouped into two different clades with an optimal bootstrap support (100\%): isolates ITA 1 and ITA 2 grouped together with AQ10, and no differences were observed between these three sequences. The fusiform-shaped conidia of ITA 1 are similar to the conidia of the commercial A. quisqualis (AQ10). The other three wild isolates, ITA 3, ITA 4, and ITA 5, grouped together with the sequence from the American Type Culture

TABLE 1. Incidence of Erysiphe necator and presence of Ampelomyces spp. on grapevine in Trentino-Alto Adige region (2004-2007)

\begin{tabular}{|c|c|c|c|c|c|c|}
\hline Year, vineyard ${ }^{\mathrm{u}}$ & $\begin{array}{c}\text { No. of } \\
\text { vineyards }\end{array}$ & $\begin{array}{c}\text { Incidence of } \\
\text { powdery mildew } \\
(\% \pm \mathrm{SE})^{\mathrm{v}}\end{array}$ & $\begin{array}{l}\text { Chasmothecia per } \\
\text { unit leaf area } \\
\left(\text { no./ } / \mathrm{cm}^{2} \pm \mathrm{SE}\right)^{\mathrm{v}}\end{array}$ & $\begin{array}{l}\text { No. of vineyards } \\
\text { with presence of } \\
\text { Ampelomyces spp. }{ }^{\mathrm{w}}\end{array}$ & $\begin{array}{c}\text { Chasmothecia parasitized } \\
\text { by Ampelomyces } \\
(\% \pm \mathrm{SE})^{\mathrm{x}}\end{array}$ & $\begin{array}{c}\text { Average of chasmothecia } \\
\text { parasitized by Ampelomyces } \\
(\%)^{\mathrm{y}}\end{array}$ \\
\hline \multicolumn{7}{|l|}{2004} \\
\hline Organic & 1 & $40.0 \pm 3.92$ & $102 \pm 10.26$ & 0 & 0 & $\ldots$ \\
\hline Untreated & 0 & & . & $\ldots$ & & $\ldots$ \\
\hline Abandoned & 1 & $100.0 \pm 0$ & $420 \pm 22.73$ & 1 & 3.0 & $\ldots$ \\
\hline \multicolumn{7}{|l|}{2005} \\
\hline Untreated & 0 & $\ldots$ & $\ldots$ & $\ldots$ & & $\ldots$ \\
\hline Abandoned & 1 & $100.0 \pm 0$ & $433 \pm 24.57$ & 1 & 3.0 & $\ldots$ \\
\hline \multicolumn{7}{|l|}{2006} \\
\hline Conventional & 35 & $30.1 \pm 3.42$ & $77 \pm 12.69$ & $6^{2}$ & $9.2 \pm 4.37$ & $1.97 \mathrm{~b}$ \\
\hline Organic & 2 & $90.0 \pm 4.21$ & $401 \pm 20.87$ & 1 & 5.0 & $\ldots$ \\
\hline Untreated & 7 & $95.0 \pm 3.29$ & $427 \pm 17.56$ & 3 & $5.7 \pm 2.33$ & $\ldots$ \\
\hline Abandoned & 1 & $100.0 \pm 0$ & $457 \pm 21.89$ & 1 & 4.0 & $\ldots$ \\
\hline Abandoned & 1 & $100.0 \pm 0$ & $521 \pm 17.96$ & 1 & 5.0 & $\ldots$ \\
\hline
\end{tabular}

u Type of monitored vineyards.

${ }^{v}$ Values are means of four replicates (25 leaves each) per vineyard. Leaves were randomly collected at the end of the growing season (after harvest, in October to November) and examined under the light microscope. Standard errors of the means are reported (SE).

w Vineyards where conidia of Ampelomyces spp. were found in at least one chasmothecia.

${ }^{x}$ Average of parasitized chasmothecia in the vineyards where parasitism was present. The percentage of parasitized chasmothecia was calculated by checking 100 chasmothecia per site.

${ }^{y}$ Average of parasitized chasmothecia in all monitored vineyards. Values followed by the same letter are not significantly different $(P \leq 0.05)$ according to the $\chi^{2}$ test followed by Ryan's multiple comparison test.

${ }^{\mathrm{z}}$ Pycnidia of Ampelomyces spp. were also found.

TABLE 2. Strains of Ampelomyces spp. found on grapevine leaves in the Trentino-Alto Adige region in the different homogeneous areas (2004-2007)

\begin{tabular}{lllll}
\hline Location & Area & Year & Type of vineyard & Conidia shape $^{z}$ \\
\hline Calliano & Trento South & 2004 & Abandoned & Fusiform \\
Sorni & Trento North & 2005 & Organic & Ellipsoidal \\
S. Michele all'Adige 1 & Trento North & 2005 & Conventional & Fusiform \\
S. Michele all'Adige 2 & Trento North & 2006 & Conventional & Ellipsoidal \\
Rovere della Luna & Trento North & 2006 & Conventional & Ellipsoidal \\
Lavis & Trento North & 2006 & Conventional & Fusiform \\
Nave S. Rocco & Trento North & 2006 & Conventional & Ellipsoidal \\
Mezzocorona & Trento North & 2006 & Untreated & Fusiform \\
Pergolese 1 & Trento South & 2006 & Conventional & Ellipsoidal \\
Pergolese 2 & Trento South & 2006 & Untreated & Fusiform \\
Maso Rover & Trento North & 2006 & Untreated & Fusiform \\
Pressano & Rovereto & 2007 & Conventional & Ellipsoidal \\
Nomi & Rovereto & 2007 & Conventional & Ellipsoidal \\
Besenello 1 & Trento South & 2007 & Conventional & Ellipsoidal \\
Besenello 2 & Trento South & 2007 & Untreated & Ellipsoidal \\
Nogaredo & Rovereto & 2007 & Conventional & Ellipsoidal \\
\hline
\end{tabular}

${ }_{\mathrm{z}}$ Twenty conidia of Ampelomyces spp. per each isolate were examined under the light microscope. 
Collection. There were $>80$ differences between the sequences of these isolates and AQ10's sequence, while these isolates differed from one another by only one base.

\section{DISCUSSION}

Powdery mildew caused by E. necator is an important disease of grapevine in the Trentino-Alto Adige region, second only to downy mildew (Plasmopara viticola). If it is not controlled (untreated or abandoned vineyards), the disease can become extremely widespread and devastating (Table 1). Chasmothecia were formed in all the monitored vineyards in each year of the study, confirming that the initiation and development of chasmothecia in Italian vineyards can occur in any year in which conditions are favorable for disease development (4). The high incidence of chasmothecia in the vineyards of the Trentino-Alto Adige region, which was associated with the absence of flag shoots in the monitored vineyards, could imply that chasmothecia are the primary inoculum and confirm previous results, which had indicated that chasmothecia represent the main source of inoculum in the spring (4).

The monitoring of powdery mildew infections carried out during the course of this 4-year study led to the detection of a highly significant relationship between the level of powdery mildew infection (incidence and severity) and the quantity of overwintering chasmothecia formed on leaves. The amount of chasmothecia was generally low in conventional vineyards and, therefore, their presence probably could be reduced by applications of an effective method of disease control during the growing season. Even if some reports have stated that most of the chasmothecia die during the winter without having any opportunity to release ascospores (4), a reduction in the number of overwintering chasmothecia by hyperparasites may nevertheless be useful for reducing the amount of primary inoculum present in the region.

In the Trentino-Alto Adige region, chasmothecia were formed on the surface of infected leaves beginning in the late summer. The many studies on E. necator chasmothecia have reported unclear and sometimes contradictory effects of environmental factors on the development of chasmothecia (8). Reports based on field studies have suggested that the formation of ascocarps is triggered by severe powdery mildew infection, drought, cold, heat, or environmental conditions that are generally unfavorable for the parasite. Host nutrition and host resistance have both been reported to affect the formation of chasmothecia (8). Our results suggest that the density of chasmothecia per unit of leaf area was mainly related to the level of disease in the vineyard, which is usually the result of complex interactions among the amount of initial inoculum, the efficacy of disease control measures, cultivar susceptibility, the physiology of the crop, and the weather conditions during the growing season. The elevation of the vineyard, which is inversely related to temperature, was not related to the concentration of chasmothecia.
A. quisqualis is one of the most successful commercialized biocontrol agents. It acts directly by invading and destroying host cytoplasm (12). The present study is the first extensive investigation of quantitative aspects of A. quisqualis on grapevine powdery mildew in Italy. Ampelomyces spp. were observed parasitizing colonies and chasmothecia of E. necator on grapevine leaves in the main viticultural areas of the Trentino-Alto Adige region, suggesting that, although at low levels, Ampelomyces spp. were naturally present in the region. This finding also adds support to the claim that chasmothecia parasitism is probably widespread wherever A. quisqualis is present (5). In Trentino, the level of natural chasmothecia parasitism by A. quisqualis on leaves was shown to be lower than that observed in New York State (5) but similar to what was reported for chasmothecia on vine bark in New York State. The conidia size of the Italian isolates was quite variable and generally longer than reported in literature (5).

Even if A. quisqualis (AQ10) was not directly used in the monitored vineyards during the studied period, it is and was used in the surrounding area. The similarity between the ITS sequences of two of the isolates and that of AQ10 may suggest that the commercial strain could have become established in the area. The fact that Ampelomyces spp. were found continuously in certain vineyards may indicate that, in some areas, they may find suitable climatic conditions for parasitism. Among the isolated Ampelomyces spp., three strains that are probably new were identified (ITA 3/ITA 4, ITA 2, and ITA 5). The ITS sequences of these strains were different from that of the commercial Ampelomyces strain (AQ10). In any case, further exhaustive studies are necessary for any inferences concerning Ampelomyces spp. population genetics.

The widespread presence of the disease at the end of the growing season did not correspond to high levels of parasitism in

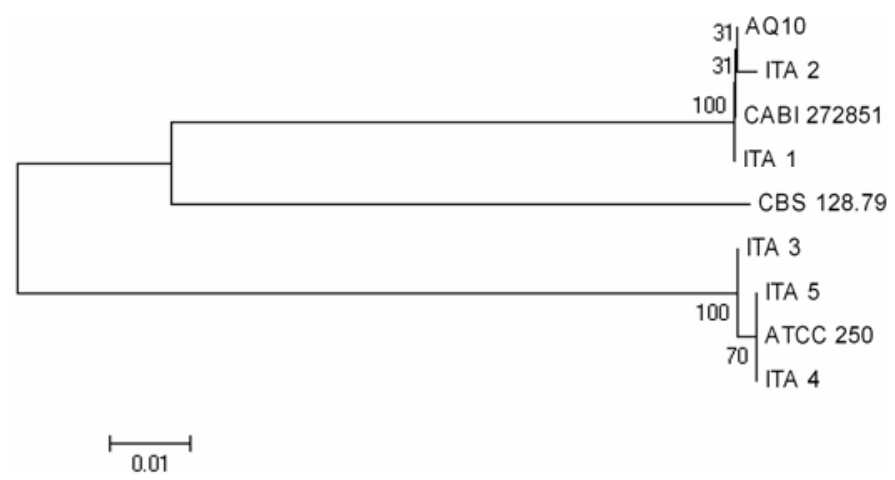

Fig. 6. Neighbor-joining tree of nine Ampelomyces spp. sequences as inferred with Mega4 software package (34) using the Jukes-Cantor substitution model and rate uniformity among sites. All gaps and missing data of the 511 characters' long alignment were eliminated. On the branches are indicated the bootstrap values. The scale bar represents the number of inferred substitutions per 100 sites (nucleotide residues).

TABLE 3. Comparison of internal transcribed spacer sequences of five wild isolates of Ampelomyces spp. found in the Trentino-Alto Adige region and other isolates from GenBank with the most similar National Center for Biotechnology Information (NCBI) library strains

\begin{tabular}{lclr}
\hline Fungal isolate & Sequence length $(\mathrm{bp})$ & \multicolumn{1}{c}{ Closest NCBI library strain $^{\mathrm{z}}$} & Similarity $(\%)$ \\
\hline ITA 1 & 589 & Ampelomyces sp. AQ10 (AF035783) & 100 \\
& $\ldots$ & Ampelomyces sp. HMLAC214 (DQ490765) & 100 \\
ITA 2 & 649 & Ampelomyces sp. AQ10 (AF035783) & 90 \\
ITA 3 & 585 & Ampelomyces quisqualis (AF126817) & 97 \\
ITA 4 & 582 & Ampelomyces quisqualis (AF126817) & 97 \\
ITA 5 & 575 & Ampelomyces quisqualis (AF126817) & 97 \\
AQ10 & 520 & Ampelomyces sp. HMLAC214 (DQ490765) & 99 \\
CBS 128.79 & 587 & Ampelomyces sp. CBS130.79 (U82449) & 99 \\
CABI 272851 & 588 & Ampelomyces sp. HMLAC214 (DQ490765) & \\
ATCC 250 & 605 & Ampelomyces quisqualis (AF126817) & 97 \\
\hline
\end{tabular}

${ }^{\mathrm{z}}$ Accession numbers given in parentheses. 
the same season. At the levels of infection observed in the Trentino-Alto Adige region, the potential for the mycoparasite to naturally reduce the levels of overwintering inoculum available for the next growing season or to impede disease development were relatively low. A few hypotheses can be raised to explain the minimal presence of A. quisqualis on E. necator in the region. The prevailing environmental conditions may not meet the requirements of the mycoparasite $(17,30)$. It is also possible that the low level of powdery mildew disease before the beginning of the survey (from 1999 to 2003) (20) may also have reduced the natural population of the mycoparasite in the area.

Numerous Ampelomyces mycoparasites are found around the world (19). Some of the A. quisqualis strains isolated in the Trentino-Alto Adige region were different from AQ10. Therefore, they may represent new isolates that are better adapted to local environmental conditions and their discovery may be the starting point of their development for use as biocontrol agents to control powdery mildew under the environmental conditions found in northern countries. Further analyses are necessary to better characterize the aggressiveness of these isolates against E. necator and their environmental requirements for development and parasitism.

\section{ACKNOWLEDGMENTS}

We thank L. Maines, D. Ress, E. Di Marino, and E. Mescalchin for the technical support and assistance. This research was supported by SafeCrop Centre, funded by Autonomous Province of Trento.

\section{LITERATURE CITED}

1. Altschul, S. F., Gish, W., Miller, W., Myers, E. W., and Lipman, D. J. 1990. Basic local alignment search tool. J. Mol. Biol. 215:403-410.

2. Angeli, D., Di Marino, E., and Mescalchin, E. 2006. Colonization of grapevine powdery mildew cleistothecia by the mycoparasite Ampelomyces quisqualis in Trentino-Alto Adige, Italy. IOBC/WPRS Bull. 29(11):89-92.

3. Bulit, J. U., and Lafon, R., 1978. Powdery mildew of the vine. Pages 525-648 in: The Powdery Mildews. Academic Press, New York.

4. Cortesi, P., Gadoury, D. M., Seem, R. C., and Pearson, R. C. 1995. Distribution and retention of cleistothecia of Uncinula necator on the bark of grapevines. Plant Dis. 79:15-19.

5. Falk, S. P., Gadoury, D. M., Cortesi, P., Pearson, R. C., and Seem R. C. 1995. Parasitism of Uncinula necator cleistothecia by the mycoparasite Ampelomyces quisqualis. Phytopathology 85:794-800.

6. Falk, S. P., Gadoury, D. M., Pearson, R. C., and Seem, R. C. 1995. Partial control of grape powdery mildew by the mycoparasite Ampelomyces quisqualis. Plant Dis. 79:483-490.

7. Felsenstein, J. 1985. Confidence limits on phylogenies: an approach using the bootstrap. Evolution 39:783-791.

8. Gadoury, D. M., and Pearson, R. C. 1988. Initiation, development, dispersal, and survival of cleistothecia of Uncinula necator in New York vineyards. Phytopathology 78:1413-1421.

9. Gadoury, D. M., Seem, R. C., Pearson, R. C., Wilcox, W. F., and Dunst, R. M. 2001. Effects of powdery mildew on vine growth, yield, and quality of Concord grapes. Plant Dis. 85:137-140.

10. Grove, G. G. 2004. Perennation of Uncinula necator in vineyards of Eastern Washington. Plant Dis. 88:242-247.

11. Hall, T. A. 1999. BioEdit: a user-friendly biological sequence alignment editor and analysis program for Windows 95/98/NT. Nucleic Acids. Symp. Ser. 41:95-98.

12. Hashioka, Y., and Nakai, Y. 1980. Ultrastructure of pycnidial development and mycoparasitism of Ampelomyces quisqualis parasitic on Erysiphales. Trans. Mycol. Soc. Jpn. 21:329-338.

13. Kiss, L. 1997. Genetic diversity in Ampelomyces isolates, hyperparasites of powdery mildew fungi, inferred from RFLP analysis of the rDNA ITS region. Mycol. Res. 101:1073-1080.

14. Kiss, L. 1998. Natural occurrence of Ampelomyces intracellular mycoparasites in mycelia of powdery mildew fungi. New Phytol. 140:709-714.

15. Kiss, L. 2003. A review of fungal antagonists of powdery mildews and their potential as biocontrol agents. Pest Manage. Sci. 59:475-483.

16. Kiss, L., and Nakasone, K. K. 1998. Ribosomal DNA internal transcribed spacer sequences do not support the species status of Ampelomyces quisqualis, a hyperparasite of powdery mildew fungi. Curr. Genet. 33:362-367.

17. Kiss, L., Russell, J. C., Szentivanyi, O., Xu, X., and Jeffries, P. 2004. Biology and biocontrol potential of Ampelomyces mycoparasites, natural antagonist of powdery mildew fungi. Biocontrol Sci. Technol. 14:635-651.

18. Larkin, M. A., Blackshields, G., Brown, N. P., Chenna, R., McGettigan, P. A., McWilliam, H., Valentin, F., Wallace, I. M., Wilm, A., Lopez, R., Thompson, J. D., Gibson, T. J., and Higgins, D. G. 2007. ClustalW2 and ClustalX version 2. Bioinformatics 23:2947-2948.

19. Liang, C., Yang, J., Kovacs, G. M., Szentivanyi, O., Li, B., Xu, X. M., and Kiss, L. 2007. Genetic diversity of Ampelomyces mycoparasite isolated from different powdery mildew species in China inferred from analyses of rDNA ITS sequences. Fungal Diversity 24:225-240.

20. Mescalchin, E., Di Marino E., and Angeli, D. 2005. Monitoraggio della presenza di Ampelomyces nei vigneti del Trentino. Terra Trentina 5:32-37.

21. Ough, C. S., and Berg, H. W. 1979. Powdery mildew sensory effect on wine. Am. J. Enol. Vitic. 30:321.

22. Page, R. D. M. 1996. Tree View: An application to display phylogenetic trees on personal computers. Comput. Appl. Biosci. 12:357-358.

23. Pearson, R. C., and Gadoury, D. M. 1987. Cleistothecia, the source of primary inoculum for grape powdery mildew in New York. Phytopathology 77:1509-1514

24. Pearson, R. C., and Goheen, A. C. 1988. Compendium of Grape Diseases. American Phytopathological Society, St. Paul, MN.

25. Rumbolz, J., and Gubler, W. D. 2005. Susceptibility of grapevine buds to infection by powdery mildew Erysiphe necator. Plant Pathol. 54:535-548.

26. Ryan, T. A. 1960. Significance tests for multiple comparison of proportions, variances, and other statistics. Psychol. Bull. 57:318-328.

27. Sall, M. A., and Wrysinski, J. 1982. Perennation of powdery mildew in buds of grapevine. Plant Dis. 66:678-9.

28. Staden, R., Beal, K. F., and Bonfield, J. K. 2000. The Staden package, 1998. Bioinform. Methods Prot. 132:115-130.

29. Sullivan, R. F., and White, J. F., Jr. 2000. Phoma glomerata as a mycoparasite of powdery mildew. Appl. Environ. Microbiol. 66:425-427.

30. Sundheim, L., and Krekling, T. 1982. Host-parasite relationships of the hyperparasite Ampelomyces quisqualis and its powdery mildew host Sphaerotheca fuliginea. I. Scanning electron microscopy. Phytopathol. Z. 104:202-210.

31. Sundheim, L., and Tronsmo, A. 1988. Hyperparasites in biological control. Pages 53-69 in: Biocontrol of Plant Diseases, Vol. I. CRC Press, Boca Raton, FL.

32. Szentiványi, O., Kiss, L., Russell, J. C., Kovács, G. M., Varga, K., Jankovics, T., Lesemann, S., Xu, X. M., and Jeffries, P. 2005. Ampelomyces mycoparasites from apple powdery mildew identified as a distinct group based on single-stranded conformation polymorphism analysis of the rDNA ITS region. Mycol. Res.109:429-438.

33. Sztejnberg, A. 1993. Ampelomyces quisqualis AQ10, CNCM I-807, for biological control of powdery mildew. US patent no. 5190754.

34. Sztejnberg, A., Galper, S., Mazar, S., and Lisker, N. 1989. Ampelomyces quisqualis for biological and integrated control of powdery mildews in Israel. J. Phytopathol. 124:285-295.

35. Tamura, K., Dudley, J., Nei, M., and Kumar, S. 2007. MEGA4: Molecular Evolutionary Genetics Analysis (MEGA) software version 4.0. Mol. Biol. Evol. 24:1596-1599.

36. White, T., J., Bruns, T., Lee, S., and Taylor, J. 1990. Amplification and direct sequencing of fungal ribosomal RNA genes for phylogenetics. Pages 315-322 in: PCR Protocols: A Guide to Methods and Applications. M. A. Innis, D. H. Gelfand, J. J. Sninsky, and T. J. White, eds. Academic Press, San Diego, CA.

37. Ypema, H. L., and Gubler, W. D. 2000. The distribution of early season grapevine shoots infected by Uncinula necator from year to year: A case study in two California vineyards. Am. J. Enol. Vitic. 51:1-6. 